\title{
A Rare Cause of Acute Abdomen; Burkitt's Lymphoma
}

\author{
Nadir Bir Akut Batın nedeni; Burkitt Lenfoma
}

Bünyami Özoğul' ${ }^{1}$, Abdullah Kısaoglu' ${ }^{1}$, Murat Sarıtemur², Atıf Bayramoğlu², Ayhan Aköz ${ }^{2}$

'Department of General Surgery, Atatürk University Medicine Faculty, Erzurum, Turkey

2Department of Emergency, Atatürk University Medicine Faculty, Erzurum, Turkey

\section{ABSTRACT}

Introduction: Burkitt lymphoma, one of the non-Hodgkin's lymphomas with aggressive behavior, frequently shows extranodal involvement.

Case Report: A 10 year-old male patient admitted to the emergency department with abdominal pain. He had significant right lower quadrant tenderness, but abdominal guarding and rebound tenderness signs were not clear. On admission, patient's white blood cell count was in normal range. Abdominal ultrasonography and intravenous contrast-enhanced abdominal computed tomography revealed periintestinal fluid around the cecum and pathological lymph nodes. The patient was hospitalized to the general surgery clinic for follow-up and treatment. Because of the patient's white blood cell count increased to $18200 / \mu \mathrm{L}$ (neutrophils $89.7 \%$ ) in follow-up he was operated urgently. A mass lesion which is localized approximately 4-5 cm proximal to the cecum and filling the lumen was detected. It had soft consistency on palpation and obstructed the lumen almost complete. The lesion was reported as Burkitt's lymphoma.

Conclusion: It is difficult to diagnose intestinal lymphoma with routine radiological methods. An alternative diagnosis should be kept in mind in the patients who admitted to the emergency department with acute abdomen.

Keywords: Acute Abdomen, Burkitt's Lymphoma

Received: 26.08.2013 Accepted: 11.09.2013

\section{ÖZET}

Giriş: Sıklıkla ekstranodal tutulum gösteren Burkitt Lenfoma, Hodgkin dışı lenfomaların agresiv davranış gösterenlerinden biridir.

Olgu Sunumu: On yedi yaşında erkek hasta karın ağrısı şikayeti ile acil kliniğine başvurdu. Sağ alt kadranda hassasiyeti belirgindi ancak defans ve rebound bulgusu şüpheliydi. İlk bakılan hemogram değerinde lökosit sayısı normal sınırlarda olan hastaya çekilen batın ultrasonografi ve intravenöz kontrastlı batın tomografisinde çekum etrafında periintestinal mayi ve patolojik lenf nodları mevcuttu. Takip ve tedavi amacıyla kliniğe yatırılan hastanın beyaz küre değerinin 18200/uL'e (nötrofil \%89,7) yükselmesi nedeniyle acil operasyona alındı. Çekumun yaklaşık 4-5 cm proksimalinde lümen içerisini dolduran palpasyonda yumuşak kıvamda, lümeni tama yakın tıkamış kitle lezyon Burkitt lenfoma olarak rapor edildi.

Sonuç: Intestinal lenfomaların rutin radyolojik yöntemler ile tanısı zordur. Acil servise gelen ve akut batın tablosuna sahip hastalarda alternatif tanılar da akılda bulundurulmalıdır.

\section{Giriş}

Lenfomalar gastrointestinal sistem (GiS) tümörlerinin \%1'ini oluşturur. Sıklık sırasına göre mide, ince barsaklar ve kolon-rektumda görülür (1). Hodgkin dışı lenfomaların primer GiS tutulumu ise \%4-20'dir. Sıklıkla ekstranodal tutulum gösteren Burkitt Lenfoma Hodgkin dışı lenfomaların agresiv davranış gösterenlerinden biridir (2). Endemik Burkitt Lenfomada çene ve yüz kemikleri, immun yetmezliğin eşlik ettiği Burkitt lenfomada lenf nodu ve kemik iliği tutulumu, sporadik olgularda ise ileoçekal bölge tutulumuna bağlı abdominal kitle ile görülür (3). 


\section{Olgu Sunumu}

On yedi yaşında erkek hastanın, epigastrik bölgede başlayan daha sonra batın sağ alt kadrana yayılan karın ağrısı şikayeti olması üzerine acil kliniğine başvurdu. Bu şikayetinin daha önce olmadığını söyleyen hastanın yapılan muayenesinde sağ alt kadranda belirgin hassasiyeti vardı, muskuler defans ve rebound şüpheli idi. Hastanın acil kliniğinde yapılan kan sayımında beyaz küre değeri 10100/ $\mu \mathrm{L}$ ve hemoglobin değeri ise 16,4 g/dL idi. Nötrofil 7300/ $\mu \mathrm{L}$ (2100-6100) ve yüzdesi 72,1 (\%41-73) idi. Biyokimya değerleri normal sınırlarda idi. Hastanın çekilen batın Ultrasonografisinde Perfore Apandisit, çekum etrafında periintestinal mayi ve büyüğü 25×18 mm ebatta olan lenf nodları mevcuttu. Hastaya çekilen alt-üst batın tomografisinde ileoçekal invaginasyon, periçekal bölgede en büyüğü 25×15 mm ebatlarında lenf nodları ve periapandiküler, periintestinal mayi olduğu belirtildi (Resim 1). Hasta takip ve tedavi amacıyla kliniği yatırıldı. Bu esnada tekrar çalışılan tam kan sayımında beyaz küre değeri 18200/ $\mu \mathrm{L}$ ve hemoglobin değeri ise 15,9 g/dL idi. Nötrofil 16300/ $\mu \mathrm{L}$ (2100-6100) ve yüzdesi 89,7 (\%41-73) idi. Bu hali ile hastaya acil operasyon planlandı. Sağ göbek altı paramedian insizyon ile yapılan eksplorasyonda apendiks normal olarak bulundu. Çekumun yaklaşık 4-5 cm proksimalinde lümen içerisini dolduran palpasyonda yumuşak kıvamda, lümeni tama yakın obstrükte etmiş kitle lezyon vardı. Acil şartlarda opere edilen hastaya sağ hemikolektomi ve ileotransvers uç-yan anastomoz yapıldı. Batın içerinde başka bir patoloji tespit edilmedi.

Spesmenin patolojik incelenmesi sonucunda makroskopik olarak $6,1 \times 4,2 \times 3,5 \mathrm{~cm}$ ebatlarında polipoid kitle lezyon vardı. Kitle serozaya invaze idi. En büyüğü $2 \times 1,5 \times 0,9 \mathrm{~cm}$ olan 5 adet metastatik lenf nodu vardı. Hastaya bu hali ile Burkitt lenfoma tanısı konularak rapor edildi.

Hasta postoperatif 7. gününde komplikasyonsuz olarak taburcu edildi. 3 hafta sonra hematoloji kliniği ile görüşülerek hasta ilgili kliniğine yatırıldı.

\section{Tartışma}

Gastrointestinal sistem lenfomaları kadınlarda daha fazla görülmekle birlikte genelde 50 yaş üzeri hastalarda görülür (4). Hastaların en belirgin semptomu karın ağrısı olmakla birlikte kusma, ishal ve kilo kaybı klinik tabloya eşlik eden diğer semptomlardır (1). Lenfomalar tüm gastrointestinal sistem malign tümörlerinin \%1'ini oluşturur. Bu tümörlerin radyolojik yöntemler ile tespit edilmesi oldukça zordur. Çoğu zaman bizim olgumuzda olduğu gibi laparatomi esnasında tanı konur. Bu tümörlerin en sık görüldüğü yerler \%50-60'ı midede, \%20-30'u ince barsaklarda ve \%10-20 oranında ise kolon ve rektumda görülür (1).

Intestinal lenfomalar genellikler unifokal olup, lamina propria'dan serozaya kadar uzanabilir (4). İleumda B hücreli lenfomalar sık gözlenirken, jejunumda görülenler daha çok T-hücreli lenfomadır. Hastaların \%80'inde terminal ileumda tek lezyon vardır (1). Jejenumda yerleşen T-Hücreli lenfomalar kalın plaklar, ülserler veya strüktürler

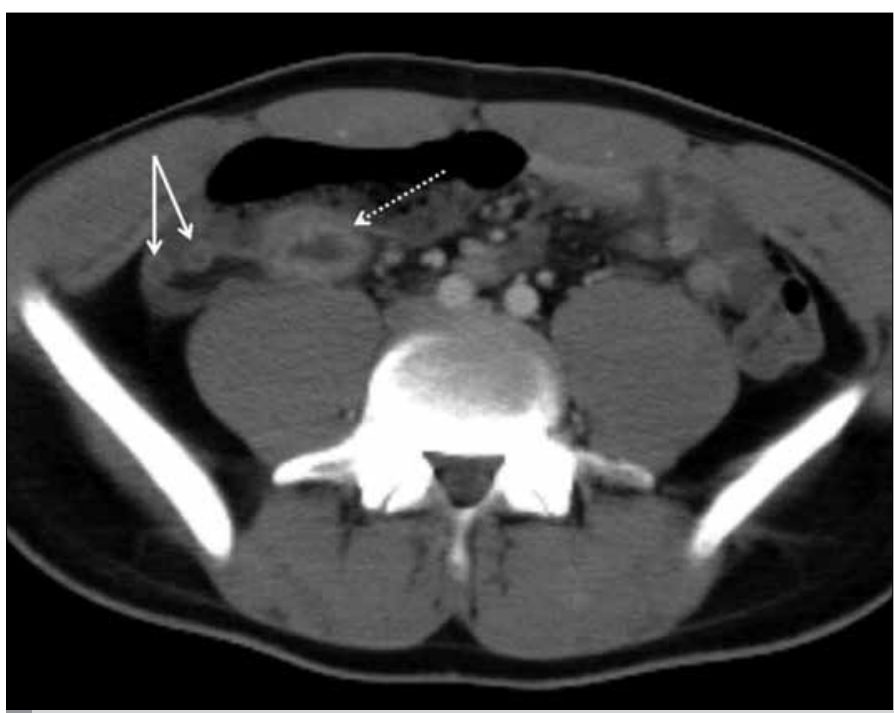

Resim 1. Kontrastlı aksiyel BT kesiti apendiks duvarındaki ödem ve kontrast artımı (oklar) izlenmektedir. BT de aynı zamanda distal ileumda ödem ve kontrast artımı (kesikli ok) izlenmektedir

şeklinde, ileumda yerleşen B hücreli lenfomalar ise ekzofitik ya da anuler şeklinde görülürler (5).

B-hücre kökenli lenfomalar klinik olarak çok agresiftir. Genelde çocuklarda görülen bu lenfomaların adult hastalarda görülme sıklığı \%1'dir. Ekstra-nodal tutulum yaygın görülmekle birlikte 3 tipi olan bu grubun sporadik formunda GiS tutulumu ön plandadır. Distal ileum, mide ve çekum en belirgin tutulum yerlerdir $(6,7)$.

Gastrointestinal lenfomalar obstrüksiyon, perforasyon, kanama ve invaginasyon ile karşımıza çıkabilir $(7,8)$. Bizim hastamızda acil serviste yapılan muayenede batında yaygın hassasiyet, özellikle sağ alt kadranda olmak üzere muskuler defans ve rebound bulguları vardı. Ayrıca hastada subileus hali vardı. Özellikle böyle klinik bulgulara sahip genç hastalarda, acil serviste değerlendirildiğinde akut apandisit hemen düşünülen tanı olarak karşımıza çıkmaktadır. Bu tanıyı doğrulamak için yapılan radyolojik tetkiklerin optimal şartlarda yapılmış olması önemlidir. Ayrıca radyolojik olarak bu hastaların değerlendirilmesine dikkat etmek gereklidir. Bu hastada yapılan radyolojik tetkikler bizi perfore apandisit tanısına doğru yönlendirmiştir. Fakat her iki tetkikte görülen lenf nodları bizim tanımızın doğruluğunu sorgulamamıza neden olmamıştır. Bu yüzden radyolojik olarak görülen lenf nodları varlığında aklımıza apandisit dışı diğer hastalıkların gelmesi gerekmektedir.

Intestinal lenfomalarda ilk tercih edilen tedavi cerrahidir. Primer cerrahi rezeksiyon ile hem tanı konulabilmekte hemde tümör rezeke edilmektedir. Hastalara cerrahi tedaviyi takiben kemoterapi ve radyoterapi uygulanmaktadır. Tedavi kararını etkileyen nedenler arasında yaş, tümörün evresi, histolojik grade ve kitle boyutu yer almaktadır. Cerrahi sonrası kemoterapi alan hastalarda sağ kalım uzamaktadır. Radyoterapi lokal nüksleri önlemekle birlikte sağkalım süresine etkisi sınırlıdır $(1,9)$. 
Cerrahi tam rezeksiyon yapılan Evre 1 ve 2 hastalarda prognoz cerrahi olmayan hastalara göre daha iyi bulunmuştur (9). Küratif rezeksiyona rağmen 5 yıllık sağ kalım Evre 1 hastalar için \%45 ve Evre 2 hastalar için ise \%19. Ileri evre hastalarda ise kombine kemoterapi ile 5 yıllık sağ kalım \%50 ve 10 yıllık sağ kalım \%20'dir (10).

\section{Sonuç}

Intestinal lenfomaların rutin radyolojik yöntemler ile tanısı zordur. Acil servise gelen ve akut batın tablosuna sahip hastalarda Acil servis uzmanları ile birlikte Genel cerrahi uzmanları alternatif tanılar üzerinde düşünerek hastaların değerlendirilmesinde optimal hassasiyeti göstermelidir.

Informed consent: Written informed consent was obtained from patient who participated in this case.

Peer-review: Externally peer-reviewed

Author contributions: Concept - B.Ö., A.K.; Design - B.Ö., M.S.; Supervision - A.K., A.B.; Materials - B.Ö., A.B.; Data Collection and/ or Processing - B.Ö., A.A.; Analysis and/or Interpretation - B.Ö., M.S.; Literature Review - A.K., A.A.; Writer - B.Ö., A.B.; Critical Review - A.K., M.S.

Conflict of interest: The authors declared no conflict of interest.

Financial Disclosure: The authors declared that this study has received no financial support.

Hasta Onamı: Yazılı hasta onamı bu olguya katılan hastadan alınmıştır.

Hakem Değerlendirmesi: Dış bağımsız.

Yazar Katkıları: Fikir - B.Ö., A.K.; Tasarım - B.Ö., M.S.; Denetleme - A.K., A.B.; Malzemeler - B.Ö., A.B.; Veri toplanması ve/veya işlemesi - B.Ö.,
A.A.; Analiz ve/veya yorum - B.Ö., M.S.; Literatür taraması - A.K., A.A.; Yazıyı yazan - B.Ö., A.B.; Eleştirel İnceleme - A.K., M.S.

Çıkar Çatışması: Yazarlar çıkar çatışması bildirmemişlerdir.

Finansal Destek: Yazarlar bu çalışma için finansal destek almadıklarını beyan etmişlerdir.

\section{Kaynaklar}

1. Zinzani PL, Magagnoli M, Pagliani G, Bendandi M, Gherlinzoni F, Merla E, Salvucci M, Tura S. Primary Intestınal Lymphoma: Clınıcal and Therapeutic Features of 32 Patıents. Haematologica 1997; 82: 305-308.

2. Jaffe ES, Harris NL, Stein H, Vardiman JW. WHO classification tumours of haematopoietic and lymphoid tissue. Lyon: IARC Press; 2001.

3. Knowles DM. Neoplastic Hematopathology. $2^{\text {nd }}$ ed. Philadelphia: Lippincot Williams-Wilkins; 2001.

4. Dilworth HP. Neoplasms of the Small Intestine. In:Lacobuzio- Donahue CA, Montgomery EA, Gastrointestinal and Liver Pathology. Goldblum JR, ed. Pennsylvania: Churchıll Livingstone; 2005. p.187-203.

5. Gascoyne RD, Muller-Hermeling HK, Chott A, WotherspoonA. Tumours of small intestine. Pathology and genetics oftumours of the digestive system. Lyon: Edited by Hamilton SR, Aaltonen LA: IARC Pres; 2000. p.83-89.

6. Isaacson PG. Gastrointestınal Lymphoma. Hum Pathol 1994; 25: 1020. [CrossRef]

7. Dawson IM, Cornes J, Morson BC. Primary malignant tumors of the intestinal tract. Report of 37 cases with a study of factors influencing prognosis. Br J Surg 1961; 49: 80-9. [CrossRef]

8. Albayrak D, Ibis AC, Hatipoğlu AR, Polat N, Hoscoskun Z. Perfore Primer İnce Barsak Lenfoması: Olgu Sunumu. Trakya Univ Tip Fak Derg 2008; 25: 60-4.

9. Crump M, Gospodarowicz M, Shepherd FA. Lymphoma of the gastrointestinal tract. Semin Oncol 1999; 26: 324-37.

10. Domizio P, Owen RA, Shepherd NA, Talbot IC, Norton AJ. Primary lymphoma of the small intestine. A clinicopathological study of 119 cases. Am J Surg Pathol 1993, 17: 429. [CrossRef] 